To appear in Huba Bartos, Marcel den Dikken, Zoltán Bánréti and Tamás Váradi, eds., Boundaries Crossed, at the Interfaces of Morphosyntax, Phonology, Pragmatics and Semantics. Studies in Natural Language \& Linguistic Theory, Springer.

\title{
Strict and non-strict negative concord in Hungarian: A unified analysis ${ }^{1}$ Anna Szabolcsi
}

Surányi (2006) observed that Hungarian has a hybrid (strict + non-strict) negative concord system. This paper proposes a uniform analysis of that system within the general framework of Zeijlstra $(2004,2008)$ and, especially, Chierchia (2013), with the following new ingredients. Sentential negation nem is the same full negation in the presence of both strict and non-strict concord items. Preverbal senki ' $\mathrm{n}$-one' type negative concord items occupy the specifier position of either nem 'not' or sem 'nor'. The latter, sem, spells out is 'too, even' in the immediate scope of negation; is/sem are focus-associating heads on the clausal spine. Sem can be seen as an overt counterpart of the phonetically null head that Chierchia dubs NEG; it is capable of invoking an abstract (disembodied) negation at the edge of its projection.

\section{The Basic Hybrid Data}

Russian is a classical strict negative concord (NC) language: the sentential negation marker ne is always obligatory in the presence of n-words. Italian is a classical non-strict NC language: the sentential negation marker non is in complementary distribution with preverbal n-words (unless the intended meaning is double negation). See Giannakidou (1997).

Hungarian is known as a strict NC language. But, alongside nikto and nichto (nichego) style senki 'n-one' and semmi 'n-thing', it also has senki sem 'n-one nor' and semmi sem 'n-thing nor'. Surányi (2006) made the fundamental observation that the distribution of the latter items is largely the same as that of nessuno and niente. He concluded that Hungarian has hybrid NC.

$\begin{array}{lllllll}\text { (1) a. } & \text { Nikto } & \text { ne } & \text { videl } & \text { nichego. } & \text { *w/o ne } & \text { 'No one saw anything', } \\ \text { (2) a. } & \text { Nessuno } & & \text { ha visto } & \text { niente. } & \text { *with non } & \text { 'No one saw anything', } \\ \text { (3) a. } & \text { Senki } & \text { nem } & \text { látott } & \text { semmit. } & \text { *w/o nem } & \text { 'No one saw anything', } \\ \text { (4) a. } & \text { Senki sem } & & \text { látott } & \text { semmit sem. } & \text { *with nem } & \text { 'No one saw anything' } \\ & & & & & \\ \text { (1) b. } & \text { Marija } & \text { ne } & \text { videla } & \text { nichego. } & \text { *w/o ne } & \text { 'M didn't see anything', } \\ \text { (2) b. } & \text { Maria } & \text { non } & \text { ha visto } & \text { niente. } & \text { *w/o non } & \text { 'M didn't see anything', } \\ \text { (3) b. } & \text { Mari } & \text { nem } & \text { látott } & \text { semmit. } & \text { *w/o nem } & \text { 'M didn't see anything', } \\ \text { (4) b. } & \text { Mari } & \text { nem } & \text { látott } & \text { semmit sem. } & \text { *w/o nem } & \text { 'M didn't see anything', }\end{array}$

As Surányi points out, sem cannot be simply the same thing as nem. Nem only occurs preverbally, but sem may accompany n-words in postverbal position as well.

The two kinds of Hungarian NC items peacefully co-exist within one sentence, as expected based on (3)-(4). To underscore this, I add a third n-word in (5). All postverbal combinations are possible: sehol semmit, sehol sem semmit sem, sehol semmit sem, sehol sem semmit.

$\begin{array}{lllll}\text { (5) a. Sen-ki nem látott se-hol (sem) } & \text { sem-mi-t } & \text { (sem). } \\ \text { N-one not saw N-place nor } & \text { N-thing-ACC } & \text { nor } \\ \text { 'No one saw anything anywhere' } & & \end{array}$

\footnotetext{
${ }^{1}$ I thank G. Chierchia, M. Esipova, A. Giannakidou, P. Jeretić, K. É. Kiss, H. Zeijlstra, and the reviewers for discussion and comments.
} 


$\begin{array}{llllll}\text { b. Mari nem látott se-hol } & \text { (sem) } & \text { sem-mi-t } & \text { (sem). } \\ \text { Mari not saw N-place nor } & \text { N-thing-ACC } & \text { nor } \\ \text { 'Mari didn't see anything anywhere' } & & \\ \text { c. Sen-ki sem látott se-hol } & \text { (sem) } & \text { sem-mi-t } & \text { (sem). } \\ & \text { N-one nor saw N-place } & \text { nor } & \text { N-thing-ACC } & \text { nor } \\ \text { 'No one saw anything anywhere' } & & & \end{array}$

These facts raise the following questions, to be refined below:

(6) How do the strict and non-strict NC systems combine in one language?

(7) Why is senki a strict NC item, and senki sem a non-strict NC item?

Surányi proposed a system with multiple ambiguities: "N-words in Hungarian can be semantically negative or non-negative, and both types are lexically ambiguous between a universally quantified and a non-quantificational interpretation" (2006: 272).

My goal is to steer clear of ambiguities. In this short paper I am not able to consider all the issues that Surányi did, but I hope that the key questions are adequately addressed. In many respects I follow Zeijlstra and Chierchia. It should be immediately noted that Surányi did not refer to these authors; his work had largely or completely preceded theirs.

\section{The Gist of the Proposal}

Zeijlstra $(2004,2008)$ treats n-words in both strict and non-strict NC languages as carriers of the uninterpretable [uNeg] feature. This is something I adopt:

(8) Following Zeijlstra, both senki and senki sem must be within the immediate scope of negation; syntactically, they carry the feature [uNeg].

On the other hand, Zeijlstra does not treat the sentential negation markers uniformly. In making the strict/non-strict distinction, he analyses Italian non as having an interpretable [iNeg] feature and expressing semantic negation $\neg$, but Czech (Russian) ne as having uninterpretable [uNeg]. The status of $n e$ is similar to that of nikto. Both are licensed by a phonetically null operator Op with a $\neg$ semantics.

Zeijlstra's divergent analyses of the sentential negation markers predict that strict and nonstrict NC do not coexist in one language. But the hybrid situation exists in Hungarian, so the sentential negation marker nem requires a unitary analysis. If [iNeg] $\neg$ versus $[\mathrm{uNeg}]$ are the only options, the former is the more straightforward choice (see also Puskás 2012):

(9) Hungarian nem has an interpretable [iNeg] feature and expresses semantic negation $\neg$, like Italian non.

This revision will also solve a major problem in Zeijlstra's account of strict NC. Since Zeijlstra's ne has just [uNeg], it remains unexplained why its presence is obligatory in all negated sentences. Zeijlstra suggests that it is part of the verbal morphology. This may well be true for Czech, but Russian ne is merely a syntactic clitic, and Hungarian nem is not even a clitic. On my proposal, Hungarian nem plays a useful role in supplying semantic negation $\neg$ and, where needed, the licensing feature [iNeg].

Let us turn to the contrast between senki (strict NCI) and senki sem (non-strict NCI). My account of non-strict negative concord will rely directly on Chierchia (2013). Chierchia explicitly follows Zeijlstra in many respects, but he revises both the semantics and the syntax. 
At this point it suffices to point out the following syntactic difference. For Zeijlstra, negation, $\neg$ is the meaning of the peripheral null operator Op that carries the [iNeg] feature that licenses [uNeg] nessuno. In contrast, Chierchia separates the syntactic licensor and negation. He introduces a null head NEG that (i) needs an agreeing nessuno in its specifier and, (ii) requires abstract negation, $\neg$, to scope right above its projection. ${ }^{2}$ On Chierchia's account, $\neg$ is entirely abstract, it has no syntactic carrier, while NEG is a vanilla null head in the syntax.

(10) a. Nessuno ha telefonato.

'No one called'

$\begin{array}{lrrrr}\text { b. } & \mathrm{Op}_{[\mathrm{iNeg}]:} & \neg \text { nessuno[uNeg] } & \text { ha telefonato } & \text { Zeijlstra } \\ \text { c. } & \mathrm{O}_{\mathrm{ALT}} & \neg[\text { nessuno[[+n-D]]} & \left.\mathrm{NEG}_{[[+\mathrm{n}-\mathrm{D}]]} \text { ha telefonato }\right] & \text { Chierchia }\end{array}$

I will argue that Hungarian preverbal sem can be seen as an overt counterpart of Chierchia's NEG with the n-word senki in its specifier:

$$
\mathrm{O}_{\mathrm{ALT}} \quad \neg\left[\text { SemP senki[[+n-D]]} \quad \text { sem }_{[[+\mathrm{+n}-\mathrm{D}]]} \quad \text { telefonált }\right] \quad \text { Szabolcsi }
$$

More generally, sem spells out is 'too, even' in the immediate scope of negation. It is a focusassociating head that must have a stressed element in its specifier. It accommodates a variety of different stressed elements, including lexical expressions and quantifiers.

I take nem to be the head of NegP and, as stated in (9), to be interpreted as $\neg$. Neg does not require a specifier, but senki can occur there and be licensed by Neg:

$$
\mathrm{O}_{\mathrm{ALT}} \quad\left[\mathrm{NegP} \text { senki[uNeg]} \quad \text { nem }_{[\mathrm{iNeg}]: \neg \text { telefonált }] \quad \text { Szabolcsi }}\right.
$$

Details are laid out below. Section 3 introduces and compares the relevant aspects of Zeijlstra's and Chierchia's theories. Turning to Hungarian, section 4 spells out the core analysis of strict negative concord, and section 5 of non-strict negative concord. Given limitations of space, I can only briefly point out that the unsurprising existential semantics for senki is plausibly matched by a somewhat surprising disjunctive semantics for sem in section 6 .

\section{Background: Zeijlstra (2004, 2008) and Chierchia (2013)}

This paper aims to contribute to the understanding of negative concord by analyzing the Hungarian hybrid, embedded within Zeijlstra's and Chierchia's theories. It is therefore important for the reader to be aware of those theories and their slightly different assumptions.

(13) exhibits Zeijlstra's syntactic features and semantic interpretations. I write "N" for his "Neg" to reduce clutter.

\begin{tabular}{|c|c|c|c|c|c|}
\hline \multicolumn{2}{|c|}{$\begin{array}{c}\text { Not NC } \\
\text { Dutch (Standard English) }\end{array}$} & \multicolumn{2}{|c|}{$\begin{array}{l}\text { Non-strict NC } \\
\text { Italian }\end{array}$} & \multicolumn{2}{|c|}{$\begin{array}{c}\text { Strict NC } \\
\text { Czech (Russian) }\end{array}$} \\
\hline niet & $\neg$ & non & {$[\mathrm{iN}]: \neg$} & ne & {$[\mathrm{uN}]$} \\
\hline niemand & $\neg \exists$ & nessuno & {$[\mathrm{uN}]: \exists$} & nikdo & {$[\mathrm{uN}]: \exists$} \\
\hline
\end{tabular}

\footnotetext{
${ }^{2}$ Chierchia's [[n-D]] feature corresponds to Zeijlstra's [uNeg] (Chierchia 2013: 233). [[n-D]] is checked by the exhaustifier $\mathrm{O}_{\mathrm{ALT}}$, whereas the negation within the scope of $\mathrm{O}_{\mathrm{ALT}}$ is needed for semantic coherence; see a brief explanation of Chierchia's semantics in section 3.
} 
(13) reflects an amendment by Penka $(2011,2012)$. While Zeijlstra proposed that nessuno, rien, and nikdo were variables, Penka argued that they need to be indefinites. Hence the $\exists$ quantifier.

Below are Zeijlstra's representations for some simple examples. Start with Italian:

$\mathrm{Op}_{[\mathrm{iN}]}: \neg$ nessuno $[\mathrm{uN}]$ ha telefonato a nessuno $[\mathrm{uN}]$.

$$
\text { Chi ha telefonato? Op}[\text { [iN]: } \neg \text { Nessuno[uN]. }
$$

'G didn't call'

'G didn't call anyone'

'No one called'

'No one called anyone'

'Who called? No one'

While Italian has an overt sentential negation marker non with the same [iN] feature and $\neg$ semantics as Op, Czech and Russian do not. I illustrate strict NC with Russian.

(19) $\mathrm{Op}_{[\mathrm{iN}]}: \neg$ Marija

(20) Op[iN]: $\neg$ Marija nikomu[uN]

(21) $\mathrm{Op}_{[\mathrm{iN}]: \neg \text { nikto[uN] }}$

(22) $\mathrm{Op}[\mathrm{iN}]: \neg$ nikto[uN] nikomu[uN] ne $[u N]$ pozvonila. ne $[u N]$ pozvonila. ne $[\mathrm{uN}]$ pozvonil. ne[uN] pozvonil.
'M didn't call'

'M didn't call anyone'

'No one called'

'No one called anyone'

$$
\text { Kto pozvonil? Op[iN]: } \neg \text { Nikto[uN]. }
$$

'Who called? No one'

$\mathrm{N}$-words are $[\mathrm{uN}]: \exists$ in both types of languages, and the preverbal ones are uniformly licensed by $\mathrm{Op}_{[\mathrm{iN}]}: \neg$. Zeijlstra supports the claim that the preverbal n-words in Russian are not licensed by ne but, rather, by a higher licensor, with the observation that regular NPIs fall within the scope of negation when preverbal. Analogous strings do not carry analogous interpretations in Italian. Again, I illustrate with Russian:
(24) $\mathrm{Op}_{[\mathrm{iN}]}: \neg$ mne
mnogo $\mathrm{NPI}$
ne $[u N]$ nuzhno.
'I don't need much'
(25) Op[iN]: $\neg$ nikomu[uN]
mnogoNPI
ne [uN] nuzhno.
'Nobody needs much'

The licensing of regular NPIs (anyone, much) is purely semantic, not a matter of featurechecking. They must fall within the scope of a decreasing operator.

Why must negative polarity items, negative concord items among them, be within the immediate scope of an (appropriate) monotonically decreasing operator? With this question we turn to Chierchia (2013).

At the heart of Chierchia's theory is the idea that NPIs in general are distinguished by the fact that they come with obligatorily active (grammaticized) alternatives. Active alternatives must be factored into meaning by alternative-sensitive operators. One such operator is the silent and non-presuppositional counterpart of the exhaustifier only, which he and the associated literature dub O. ODA is specialized for subdomain alternatives, and works as follows.

(26) \# There are any cookies left.

Assertion: $\quad \exists x \in D$ [cookies( $x) \& \operatorname{left}(\mathrm{x})]$

Alternatives: $\left\{\exists \mathrm{x} \in \mathrm{D}^{\prime}[\operatorname{cookies}(\mathrm{x}) \& \operatorname{left}(\mathrm{x})]: \mathrm{D}^{\prime} \subseteq \mathrm{D}\right\}$

Exhaustified: ODA $\left\{\exists \mathrm{x} \in \mathrm{D}^{\prime}[\operatorname{cookies}(\mathrm{x}) \& \operatorname{left}(\mathrm{x})]: \mathrm{D}^{\prime} \subseteq \mathrm{D}\right\} \quad$ contradicts assertion 
(27) There aren't any cookies left.

Assertion: $\quad \neg \exists \mathrm{x} \in \mathrm{D}[\operatorname{cookies}(\mathrm{x}) \& \operatorname{left}(\mathrm{x})]$

Alternatives: $\quad\left\{\neg \exists \mathrm{x} \in \mathrm{D}^{\prime}[\operatorname{cookies}(\mathrm{x}) \& \operatorname{left}(\mathrm{x})]: \mathrm{D}^{\prime} \subseteq \mathrm{D}\right\}$

Exhaustified: ODA $\left\{\neg \exists \mathrm{x} \in \mathrm{D}^{\prime}[\operatorname{cookies}(\mathrm{x}) \& \operatorname{left}(\mathrm{x})]: \mathrm{D}^{\prime} \subseteq \mathrm{D}\right\} \quad$ no contradiction

ODA negates those alternatives that are not entailed by the assertion. In a monotone increasing context like (26), this leads to a contradiction. "There are cookies left" does not entail the subdomain alternative "There are cookies left on the table", so the latter is negated by ODA. But systematically negating all such alternatives leaves no chance for "There are cookies left" to be true. In contrast, in a monotone decreasing environment like (27), the subdomain alternatives are all entailed by the assertion: "There aren't cookies left" entails "There aren't cookies left on the table", and so on. ODA does not negate entailed alternatives. This is the reason why NPIs are acceptable in a decreasing environment.

Skipping some details, n-words (NCI) are a subspecies of strong negative polarity items. They must be exhaustified with respect to both subdomain and scalar alternatives in one breath. The inseparable combination of $\mathrm{O}_{\mathrm{DA}}$ and $\mathrm{O}_{\sigma \mathrm{A}}$ is notated as $\mathrm{O}_{\mathrm{ALT}}$. NCIs carry a $[[\mathrm{n}-\mathrm{D}]]$ feature that must be checked by $\mathrm{O}_{\mathrm{ALT}}$ (and become $[[+\mathrm{n}-\mathrm{D}]]$ ). [[n-D]] corresponds to an unchecked $[\mathrm{uN}]$ feature. Compare $(10 \mathrm{~b}, \mathrm{c})$ above. Contradictions caused by OALT can only be averted if the alternatives come with an end-of-scale decreasing operator such as negation; they are not averted by few, for example. See Chierchia (2013: 221).

In this theory, the peculiarity of NCIs is that they can support a phonetically null NEG head by occurring in its specifier and agreeing with it with respect to [[n-D]]. To repeat,

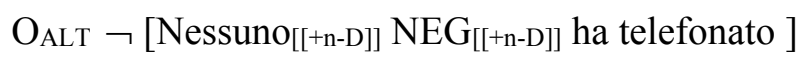

Both nessuno and NEG acquire the + value on their [[n-D]] feature from $\mathrm{O}_{\text {ALT. }}$. The abstract negation $\neg$ serves to maintain semantic coherence in the presence of $\mathrm{O}_{\text {ALT }}$.

Note that while Chierchia's NEG needs the NCI, the NCI does not need NEG. It needs OALT and, consequently, a negation. When an NCI is postverbal, that negation is either contributed by non (29) or invoked by NEG, with another NCI in its specifier (30).

(29) OALT [Gianni non

ha telefonato a nessuno $[[+n-D]]]$

(30) $\mathrm{O}_{\mathrm{ALT}} \neg\left[\mathrm{Nessuno}[[+\mathrm{+n}-\mathrm{D}]]_{\mathrm{NEG}} \mathrm{N}_{[+\mathrm{n}-\mathrm{D}]]}\right.$

ha telefonato a nessuno $[[+\mathrm{n}-\mathrm{D}]]]$

Chierchia (2013: 239) tentatively treats ne in strict-NC languages as an overt variant of NEG that relies on a distinct abstract $\neg$ operator. But that cannot be quite right. NEG requires an nword in its specifier, but ne occurs on its own (only when the meaning is negative).

This may be the appropriate point to comment on the abstractness of the negation $\neg$ invoked by NEG. Is it legitimate to postulate semantic operators without syntactic carriers? I believe it is. Szabolcsi (2015) appealed to join $(\cup)$ and meet $(\cap)$ operators that are abstract in exactly the same way, called them "disembodied", and suggested that disembodiment may be the norm for logical semantic actors.

Note that disembodied operators do not show up haphazardly. Szabolcsi (2015) proposed that disembodied join $(\cup)$ and meet $(\cap)$ may come into play in two ways. They either satisfy presuppositions triggered by overt particles, or appear by default elsewhere. For defaults, think of the routinely invoked existential closure operation $(\cup)$, and of the conjunctive interpretation of stringing sentences together in a text $(\cap)$. In Chierchia (2013), the $\neg$ operator resolves the contradiction arising from certain instances of exhaustification by OALT. (In Zeijlstra's theory, the null Op interpreted as $\neg$ is syntactic, not disembodied.) Presupposition satisfaction, default 
interpretation, and contradiction resolution seem like reasonable ways to invoke disembodied operators. An explicit theory of disembodiment is called for, but it cannot be attempted here.

\section{Strict Negative Concord in Hungarian}

This section offers an analysis of strict negative concord, with some modifications of the theories just reviewed. I start with a bit of a background for the analysis.

Pre-Zeijlstra, strict NC had often been analyzed as involving universals scoping directly above sentential negation. See Szabolcsi (1981: 528-535) and Surányi (2006) for Hungarian; Giannakidou (2000, 2006), though not Giannakidou (1997), for Modern Greek, and Shimoyama (2011) for Japanese. The arguments in these works were language-specific, but they had a common thread. N-words should fall under the same generalizations concerning linear order and prosody that apply to other quantifiers in the given language. The authors found that the position and stress of n-words suggested that they were scoping right above sentential negation in their languages. If so, they had to be universals; they could not be existentials within the scope of negation.

For example, Szabolcsi (1981) argued, in agreement with É. Kiss (1981) and Hunyadi (1981), that Hungarian supports the following descriptive generalizations (setting contrastive topics aside). The generalizations were based on the behavior of universals, indefinites, modified numerals, and all manner of other quantificational expressions.

(31) In the preverbal field, left-to-right order maps to c-command and thus to scopal order.

(32) A stressed operator outscopes a de-stressed one.

$\mathrm{NC}$ items may either precede or follow sentential negation nem; in both cases, the NC item can be stressed (the received view at that time was that it has to be stressed).
a. SENKI nem szólt.
'No one spoke'
b. $\quad$ Nem szólt
SENKI.
'No one spoke'

On the other hand, universals formed with minden are barred from scoping immediately above negation, however emphatic a denial might be:
a. ${ }^{*} \quad$ MINDEN-KI nem szólt. every-one not spoke
b. ${ }^{*} \quad$ Nem szólt MINDENKI.
c. NEM szólt mindenki.

$$
\begin{aligned}
& \text { intended, } * \forall>\neg \\
& \text { intended, } * \forall>\neg \\
& \text { 'Not everyone spoke' }
\end{aligned}
$$

It seemed natural to conclude that senki, semmi serve to express $\forall>\neg$ and fill the gap left by minden.

The $\forall>\neg$ analysis of negative concord encounters various difficulties with further data; these are detailed in Surányi (2006). One of the striking observations that Surányi makes parallels Zeijlstra's argument involving mnogo 'much' in (24)-(25). Egy SZÓ is a minimizer.

$$
\begin{aligned}
& \text { Egy SzÓ-T nem szólt-am. } \\
& \text { one word-ACC not spoke-1sg } \\
& \text { 'I didn't say a word' }
\end{aligned}
$$


(36) SENKI egy SZÓ-T nem szólt.

$\mathrm{N}-\mathrm{one}$ one word-ACC not spoke

'No one said a word'

These examples flatly refute the assumption that all stressed operators preceding nem scope over nem. Egy SZÓT clearly scopes under nem. But then SENKI in (36) can do so, too. We have seen, though, that Surányi ended up with a multiple-ambiguities analysis. ${ }^{3}$

Here is how I propose to solve the problem of Hungarian strict NC. First, as was anticipated in (9), I propose, deviating from both Zeijlstra and Chierchia, that Hungarian nem expresses semantic negation $\neg$ just like Dutch niet, English not, and Italian non, and is as independent of $\mathrm{NC}$-items as those are.

The generalization that linear precedence maps to c-command in the preverbal field has been cashed out in terms of a cartographic analysis in the intervening decades; see among many others Szabolcsi (1997), É. Kiss (2002), and Brody \& Szabolcsi (2003). For example, the universal in (34a) would be sitting in the specifier of the Dist(ributive) head, as in (37).

$$
\begin{aligned}
& \text { \# [DistP } \quad \text { minden-ki [Dist' Dist }[\mathrm{NegP} \text { nem } \exists \text { e szólt (e) ...]]] } \\
& \text { every-one not spoke }
\end{aligned}
$$

In line with standard assumptions of event semantics, Beghelli \& Stowell (1997) propose that Dist must scope directly over an existential quantifier over events $(\exists \mathrm{e})$, its distributed share. But negation inescapably scopes above the event quantifier, and so Dist is deprived of its distributed share. Therefore (37), which would yield every $>$ not, is unacceptable. ${ }^{4}$

In contrast, 'most of the children' occupies the specifier of the Ref(erential) head, which does not need a distributed share $\exists$ e. It happily scopes directly above negation and, indeed, six $>$ not is the only possible interpretation in (38).

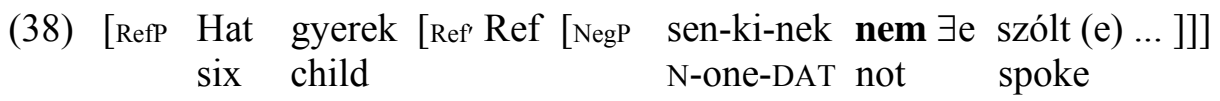

'Six children didn't speak to anyone'

In the spirit of Zeijlstra and Chierchia, we now need an analysis for (36) where senki and egy SZÓT precede nem but scope under, not over, nem. ${ }^{5}$ They cannot be in the specifier of a

\footnotetext{
${ }^{3}$ A new argument in Surányi (2006) for the universal interpretation of some n-words is that in prefocus position, they must be specific. But pre-focus existential-based NPIs that are licensed by extraclausal negation must likewise be specific, and they cannot be construed as universals. Therefore, the specificity requirement in pre-focus position probably has to be captured in some different way.

(i) Nem hisz-em, hogy \{vala-ki is / ?? vala-hány lány is \} ZOLI-T választotta. not think-1sg that some-one too some-number girl too Zoli-ACC chose

'I don't think that anyone (from a known group)/any number of girls chose ZOLI'

${ }^{4}$ Such an explanation of the scope restriction will also prevent universal senki from filling in for mindenki. But I am abandoning that 1981 assumption anyway.

${ }^{5}$ I maintain that the requirement is in terms of scope, not c-command, in agreement with Hoeksema (2000:123): "It is argued that triggering is sensitive to the scope of negation and negative operators, but that a syntactic treatment in terms of c-command is problematic, because semantic scope and syntactic c-command, no matter how we define the latter, and at which level we check it, do not see eye to eye on all the relevant cases." The reason why it may seem that decreasing operators must ccommand polarity-sensitive items at spell-out is that such operators do not take inverse scope and polarity-sensitive items do not automatically lower into their scope.
} 
functional head above NegP. But they can be in the specifier of Neg itself. When such matters are discussed explicitly, an indefinite or set-denoting expression in the specifier of an operator head is assumed to be within the scope of that head (e.g. Beghelli \& Stowell (1997), Brody \& Szabolcsi (2003)). In our case, senki and egy SzÓT are possibly remnant-moved there, which even gives them an extra reason to be taking low scope: remnant movement must reconstruct. The distinction between quantifiers that take scope above vs. below negation when they precede negation can be made thanks to the fact that syntactic theory offers more analytical options today than it did in 1981. Roughly, the structure is this, assuming V-to-T for simplicity:

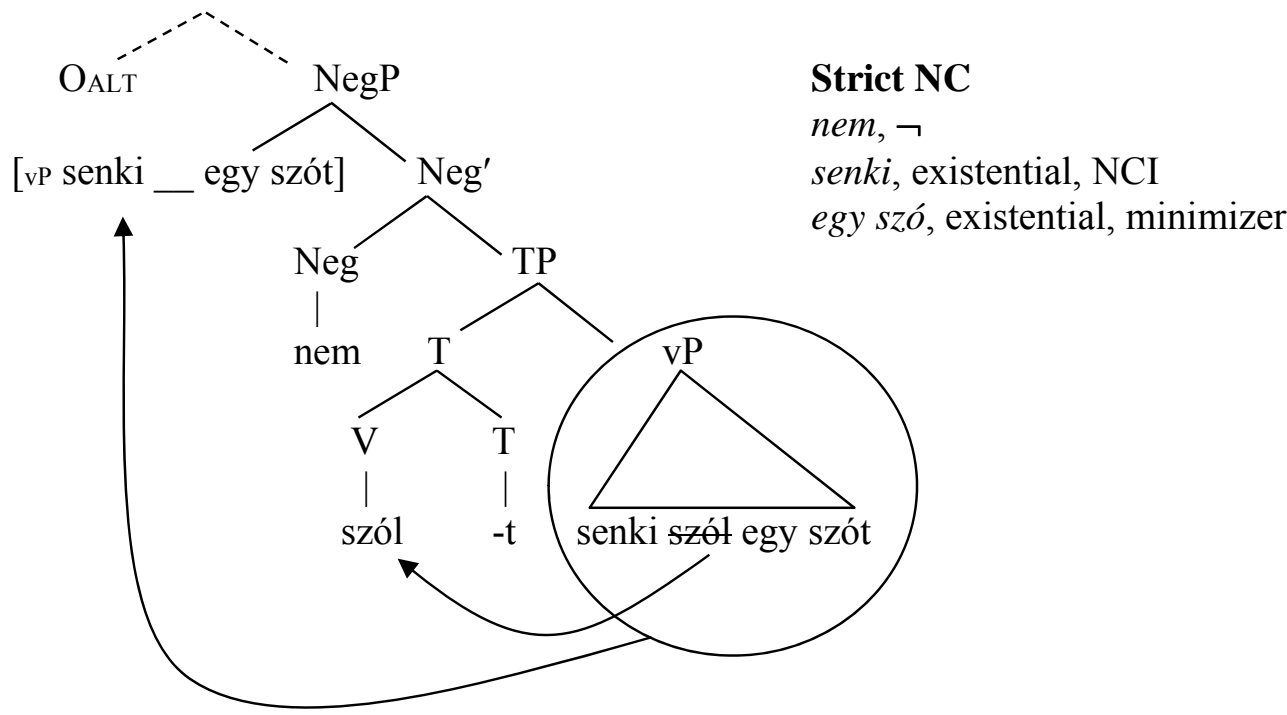

The fact that the minimizer can occur in the specifier of nem and thus within the scope of the negation that nem expresses makes it unnecessary to appeal to a higher Op: $\neg$ for the sentential negation marker in Hungarian, voiding Zeijlstra's argument based on NPIs, cf. (24)-(25). ${ }^{6}$

What about the stress generalization? Experimental work in recent years (e.g. Surányi \& Turi 2017) has shown that the correlation between higher stress and wider scope is not as clearcut as it had been thought. I do not claim to have a full understanding of the stress facts, but they do not appear to constitute a strong reason to reject the proposed analysis.

\section{Non-strict Negative Concord in Hungarian}

Let us now turn to non-strict NC. The status of nem is no longer an obstacle to the unified analysis of the two types of NC: nem expresses $\neg$ in all its occurrences.

As was anticipated in (11), the sem of preverbal senki sem can be seen as an overt version of Italian NEG in Chierchia's (2013): both are heads in the same region of the clausal spine, and both are capable of activating a disembodied $\neg$ right above their maximal projections:

$$
\mathrm{O}_{\mathrm{ALT}} \neg\left[\text { nessuno[[+n-D]] } \mathrm{NEG}_{[[+\mathrm{n}-\mathrm{D}]]} \text { ha telefonato }\right]
$$

\footnotetext{
${ }^{6}$ Two issues are left for further research. (i) The fact that the counterparts of (24)-(25) are not available in Italian would be easily predicted if non, in contrast to nem, were a specifier and not a head in NegP. But non is standardly viewed as a head, so the explanation of the cross-linguistic contrast must lie elsewhere. (ii) The fact that Ki szólt? -- Senki. serve as canonical question-answer pairs (cf. 'Who spoke? -- No one') may require the assumption of an elided nem in the fragment answer, cf. Giannakidou (2000: 486) for Modern Greek.
} 

$\mathrm{O}_{\mathrm{ALT}} \neg[\operatorname{senki}[[+\mathrm{n}-\mathrm{D}]]$
$\operatorname{sem}_{[[+n-D]]}$
telefonált ]

However, unlike NEG, sem does not specifically require an n-word in its specifier. Sem spells out the focus-associating particle is 'too, even' under negation. What it needs in its specifier is some XP with focus accent. E.g.,

(42) Egy SzÓT sem szóltam.

(43) MARINAK sem szóltam.

(44) * Sem szóltam.
'I didn't say a word'

'I didn't speak to Mari, either'

Sem will be discussed a bit further in section 6, but this short paper concentrates on NC.

(45)

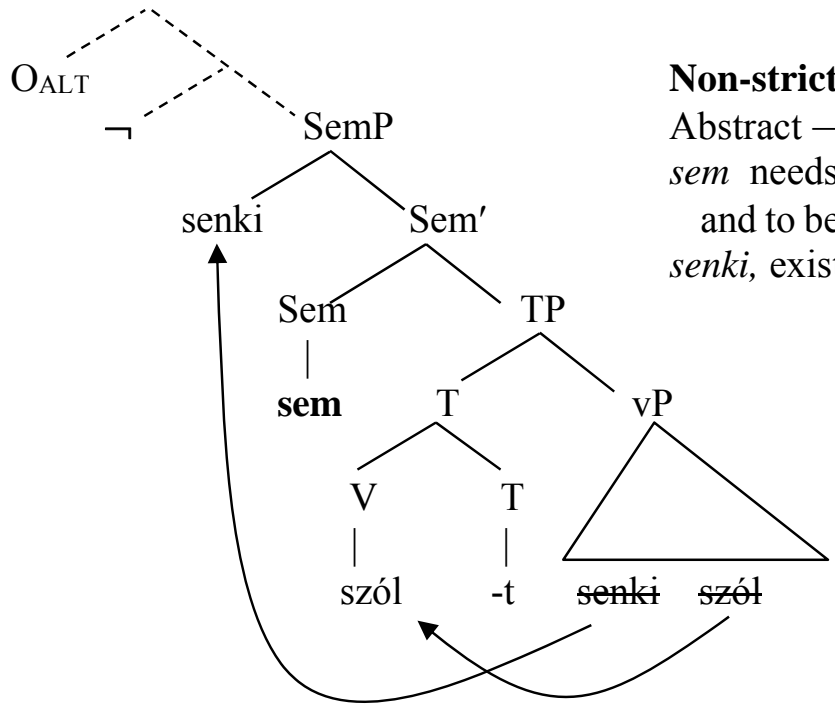

The Hungarian surface scope data show that the abstract (disembodied) $\neg$ scopes right at the edge of the preverbal SemP, supporting Chierchia's assumptions about NEG. Linearly preceding quantifiers and indefinites happily scope over the negation that licenses the NC item. They are sitting in the specifier of the functional head RefP above SemP. Notice that (46), with sem in the place of nem, exhibits the same unambiguous six $>$ not scope relation as (38).

$$
\begin{aligned}
& \text { [RefP Hat gyerek }\} \text { [Ref' Ref OALT } \neg\left[\begin{array}{llll}
\text { SemP } & \text { sen-ki-nek sem } & \text { szólt }]
\end{array}\right] \\
& \text { six child }
\end{aligned}
$$

'Six children didn't speak to anyone'

Now recall from (5) that the string senki sem occurs both preverbally and postverbally. That is fully compatible with the SemP analysis but confirms that, for independent reasons, sem is not an exact replica of Chierchia's NEG.

Szabolcsi (1997), Brody \& Szabolcsi (2003), and Bernardi \& Szabolcsi (2008) argue that almost the same functional sequence of operator heads (fseq) that occurs above T (Agr in those papers) and forms the preverbal operator field reiterates itself between $\mathrm{T}$ (Agr) and V.

$$
[\mathrm{C} \text { fseq }[\mathrm{T} \text { fseq }[\text { Asp fseq ... [V ...]]]] }
$$

Therefore, postverbal senki may reside in the SemP of a lower fseq. In that case, too, sem and its specifier senki must be in the immediate scope of clause-mate negation. That negation will be supplied by nem, as in $(5 \mathrm{a}, \mathrm{b})$, or by the $\neg$ invoked by a preverbal sem, as in $(5 \mathrm{c})$, repeated 
as (48):

$\begin{array}{lll}\text { (48) a. Senki nem látott sehol (sem) semmit (sem). } & \text { 'No one saw anything anywhere' } \\ \text { b. Mari } & \text { nem látott sehol (sem) semmit (sem). } & \text { 'Mari didn't anything anywhere' } \\ \text { c. } \neg \text { Senki } & \text { sem látott sehol (sem) semmit (sem). } & \text { 'No one saw anything anywhere' }\end{array}$

On this proposal, both NEG and sem are clausal heads that need specifiers, must be in the immediate scope of clause-mate negation, and are capable of invoking an abstract $\neg$ at the edge of their projections when they are in the appropriate region of the clausal spine. The fact that Italian has only one NEG per clause and it occurs in such a region gives the impression that invoking $\neg$ is a necessary, not just a possible, part of the package. But there is no principled reason why that should be the case. Sem differs from NEG due to the fact that Hungarian reiterates fseq, and sem can occur in any of the iterations.

Why can $\neg$ only be invoked in the highest fseq? The one major difference between the fseq above $\mathrm{T}$ and the ones below $\mathrm{T}$ is that only the first comes with Neg (overt nem). See especially Bernardi \& Szabolcsi (2008: Sections 6,8). Based on Zanuttini (1997), it appears that languages choose the position of their negations in particular ways; Cinque (1990) does not even include $\mathrm{Neg}$ in his invariant sequence. It is plausible that abstract $\neg$ is restricted to the same region where Neg resides in the given language. But this may not be the full answer.

We have not yet considered constituent negation in this context. Kenesei (2009) offers a cornucopia of examples where an NCI occurs within the scope of a constituent-negated expression and the sentence is ungrammatical. For example,

* Nem minden-ki dicsért sen-ki-t. not every-one praised N-one-ACC

Intended, unavailable 'Not everyone praised anyone'

* Nem Anná-t dicsérte sen-ki. not Anna-ACC praised N-one Intended, unavailable 'It was not Anna whom anyone praised'

I attribute the unacceptability of these examples to the fact that a universal quantifier or exhaustive focus intervenes between negation and the NCI. Like negative polarity items in general, NCI must be within the immediate scope of negation, meaning that at most plain existential quantifiers may intervene (e.g. Chierchia 2013: Chapter 7). Compare:

\# Not everyone praised anyone.

\section{Sem: A disjunction-based Particle Under Negation}

Historically, sem combines is 'too, even' and nem 'not'. Present-day sem forms NCIs that occur only with clause-mate negation (overt or abstract). Modern Greek oute has the same etymology (Classical Greek ou 'not' + te 'and, both') and similar properties (Giannakidou 2007). É.Kiss (2015) discusses Jespersen-cycle style changes in the form and strength of Hungarian negation.

Senki 'n-one' and valaki 'someone' form a NCI-PPI pair. Both are existentials. Senki must, and valaki must not, occur within the immediate scope of clause-mate negation. What about sem and is? They also form a NCI-PPI pair: sem must, and is must not, occur within the immediate scope of clause-mate negation. It would make sense to attribute a parallel, existential/disjunctive semantics to sem and is. 
English too being an additive particle, its usual analysis is conjunctive. Szabolcsi (2017) proposes to derive that through the exhaustification of a set (disjunction) of focus alternatives, following Bowler (2014) and Singh et al. (2016), among others; they have analyzed seemingly conjunctive particles as underlying disjunctions that are strengthened in a positive context. The proposal extends to Hungarian is. But Szabolcsi (2017) argues that is requires a more abstract analysis, because it also productively builds NPIs. She proposes that is in general grabs a set of alternatives induced by its specifier (focus-alternatives or subdomain-alternatives) and activates them. That is, it forces those alternatives to be exhaustified by some other operator, along the lines of Chierchia (2013) and the literature just cited.

In this spirit, I put forth the following descriptive generalizations:

(52) Senki 'n-one' and valaki 'someone' are quantifier words with existential particles

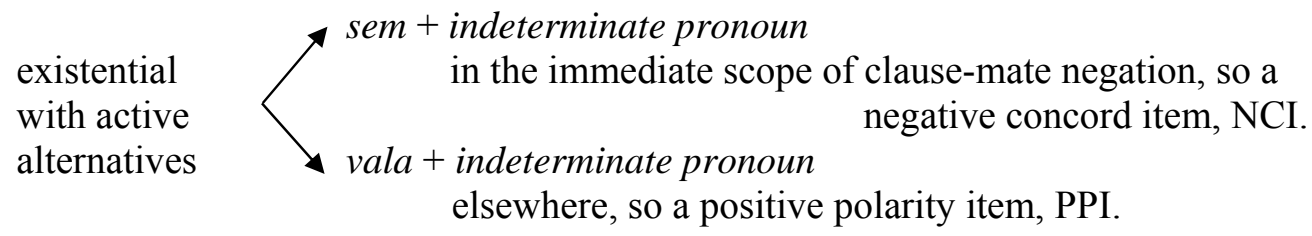

(53) Sem 'nor' and is 'too' are clausal heads with alternative-inducing specifiers

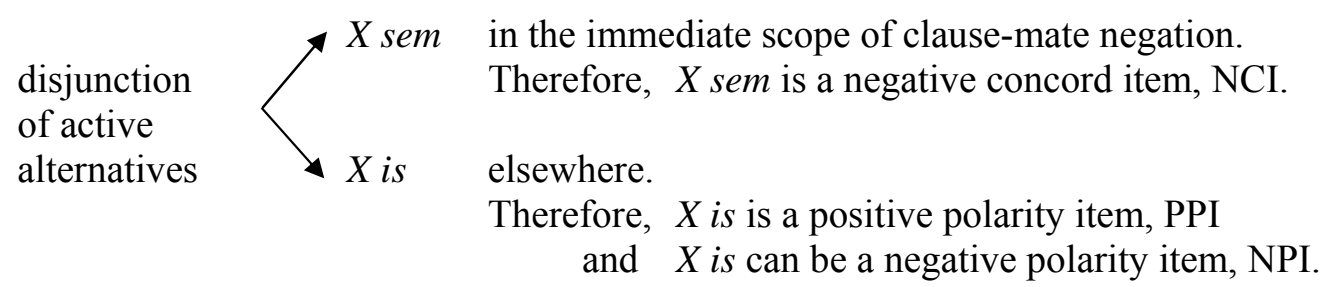

Compare egy szót sem and semmit sem, which are NCIs, with egy szót is and valamit is, which are PPIs and weak NPIs at the same time:

$$
\begin{aligned}
& \text { Nem szólt-am \{egy szó-t sem / sem-mi-t sem } \text {. } \\
& \text { not spoke-1sg one word-ACC sem / N-thing-ACC sem } \\
& \text { 'I didn't say even one word / anything' } \\
& \begin{array}{l}
\text { Kevés gyerek szólt fegy szó-t is / vala-mi-t } \\
\text { few child spoke one word-ACC is / some-thing-ACC is } \\
\text { 'Few children said even one word / anything' }
\end{array}
\end{aligned}
$$

The above correspondences are very natural in view of Progovac (1992), Krifka (1995), Lahiri (1998), Szabolcsi $(2002,2004)$ and Chierchia (2013). The roles of sem in (52) and (53) are further studied in Szabolcsi (2018).

\section{References}

Beghelli, Filippo and Timothy Stowell. 1997. Distributivity and negation: the syntax of EACH and EVERY. In Ways of Scope Taking, ed. Anna Szabolcsi, 71-108. Dordrecht: Springer.

Bernardi, Raffaella and Anna Szabolcsi. 2008. Optionality, scope and licensing: an application of partially ordered categories. Journal of Logic, Language and Information 17:237-283. 
Bowler, Margit. 2014. Conjunction and disjunction in a language without 'and'. Semantics and Linguistic Theory 24:137-155.

Brody, Michael and Anna Szabolcsi. 2003. Overt scope in Hungarian. Syntax 6:19-51.

Chierchia, Gennaro. 2013. Logic in Grammar. Oxford: Oxford University Press.

Cinque, Guglielmo. 1990. Adverbs and Functional Heads. Oxford: Oxford University Press

É. Kiss, Katalin. 1981. Structural relations in Hungarian, a "free" word order language. Linguistic Inquiry 12:185-213.

É. Kiss, Katalin. 2002. The Syntax of Hungarian. Cambridge: Cambridge University Press.

É. Kiss, Katalin. 2015. A negative cycle in 12-15th century Hungarian. In Syntax over Time: Lexical, Morphological, and Information-Structural Interactions, eds. Teresa Biberauer and George Walkden, 86-101. Oxford: Oxford University Press.

Giannakidou, Anastasia. 1997. The Landscape of Polarity Items. Dissertation, University of Groningen.

Giannakidou, Anastasia. 2000. Negative ... concord? Natural Language \& Linguistic Theory 18:457-523.

Giannakidou, Anastasia. 2007. The landscape of EVEN. Natural Language \& Linguistic Theory 25:39-81.

Hoeksema, Jack. 2000. Negative polarity items: triggering, scope, and c-command. In Negation and Polarity. Semantic and Syntactic Perspectives, eds. Laurence Horn and Yasuhiko Kato, 123-154. Oxford: Oxford University Press.

Hunyadi, László. 1981. A nyelvi polaritás kifejezése a magyarban ['The Expression of Linguistic Polarity in Hungarian']. Dissertation, Hungarian Academy of Sciences.

Kenesei, István. 2009. Quantifiers, negation and focus on the left periphery of Hungarian. Lingua 119:564-591; erratum Lingua 120: 1858-1885.

Krifka, Manfred. 1995. The semantics and pragmatics of polarity items. Linguistic Analysis 25:209-257.

Lahiri, Utpal. 1998. Focus and negative polarity in Hindi. Natural Language Semantics 6:57123.

Penka, Doris. 2011. Negative Indefinites. Oxford: Oxford University Press.

Penka, Doris. 2012. Negative features on negative indefinites: evidence from split scope. Journal of Semantics 29:373-402.

Progovac, Ljiljana. 1992. Polarity in Serbo-Croatian: Anaphoric NPIs and Pronominal PPIs. Linguistic Inquiry 22:567-572.

Puskás, Genoveva. 2012. Licensing double negation in NC and non-NC languages. Natural Language \& Linguistic Theory 30:611-649.

Singh, Raj et al. 2016. Children interpret disjunction as conjunction: Consequences for theories of implicature and child development. Natural Language Semantics 24:305-352.

Shimoyama, Junko. 2011. Japanese indeterminate negative polarity items and their scope. Journal of Semantics 28:413-450.

Surányi, Balázs. 2006. Quantification and focus in negative concord. Lingua 116:272-313.

Surányi, Balázs and Gergő Turi. 2017. Focus and quantifier scope: an experimental study in Hungarian. In Approaches to Hungarian 15: Papers from the 2015 Leiden Conference, eds. Harry van der Hulst and Anikó Lipták, 209-239. Amsterdam: John Benjamins.

Szabolcsi, Anna. 1981. The semantics of topic-focus articulation. In Formal Methods in the Study of Language, eds. Jeroen Groenendijk, Theo Janssen, and Martin Stokhof, 513-541. Amsterdam: Mathematisch Centrum.

Szabolcsi, Anna. 1997. Strategies for scope taking. In Ways of Scope Taking, ed. Anna Szabolcsi, 109-154. Dordrecht: Springer.

Szabolcsi, Anna. 2002. Hungarian disjunctions and positive polarity. In Approaches to Hungarian 8, eds. István Kenesei and Péter Siptár, 217-241. Budapest: Akadémiai Kiadó. 
Szabolcsi, Anna. 2004. Positive polarity--negative polarity. Natural Language and Linguistic Theory 22:409-452.

Szabolcsi, Anna. 2015. What do quantifier particles do? Linguistics and Philosophy 38:159204.

Szabolcsi, Anna. 2017. Additive presuppositions are derived through activating focus alternatives. Proceedings of the 21st Amsterdam Colloquium, 455-465. http://events.illc.uva.nl/AC/AC2017/Proceedings/

Szabolcsi, Anna. 2018. Two types of quantifier particles: quantifier-phrase internal vs. heads on the clausal spine. Under revision for a journal. https://www.nyu.edu/projects/szabolcsi/szabolcsi_research.html

Zanuttini, Raffaella. 1997. Negation and Clausal Structure: A comparative study of Romance languages. Oxford: Oxford University Press.

Zeijlstra, Hedde. 2004. Sentential Negation and Negative Concord. Dissertation, University of Amsterdam.

Zeijlstra, Hedde. 2008. Negative concord is syntactic agreement. lingbuzz/000645. 